\title{
Morphological Characterization of Local and Introduced Finger millet (Elusine coracana (L.) Gaertn) Germplasm in Sri Lanka
}

\author{
W.M.R. Kumari*, D.K.N.G. Pushpakumara ${ }^{1}$, W.M.W. Weerakoon ${ }^{2}$ \\ D.M.J.B. Senanayake ${ }^{3}$ and H.D. Upadhyaya ${ }^{4}$
}

Field Crops Research and Development Institute

Mahailuppallama

Sri Lanka

\begin{abstract}
Finger millet, a self-pollinated cereal crop with high nutritional value, is grown in arid and semiarid tropics. Plant Genetic Resource Center of Sri Lanka conserves 462 local and introduced finger millet (Elusine coracana (L.) Gaertn) germplasm accessions. A total of 139 accessions were morphological characterized using 14 quantitative characters during two seasons in late Maha 2016 and Maha 2016/17 at Field Crops Research and Development, Institute, Mahailluppallama. The highest variability was observed in grain yield, panicle exertion, weight of 20 mature ears, number of productive tillers and length of the longest finger. Correlation analysis showed that the grain yield was significantly and positively correlated with the number of productive tillers, weight of 20 mature ears, threshing ratio and panicle exertion. However, the grain yield was significantly and negatively correlated with flag leaf width and 1,000 grain weight. Hence, these traits can be used for selecting germplasm for improvement. The Principal Component Analysis showed that the first six principal components with eigenvalue greater than 0.8 have contributed to $78 \%$ of total variability. Eight different clusters were formed in cluster analysis based on first six principal component scores. Two major clusters (1 and 3) were consisted with 55\% of total accessions. The main traits contributed to separate genotypes into different clusters were grain yield, weight of 20 mature ears, days to $50 \%$ flowering and 1000 grain weight. The Sri Lankan finger millet germplasm collection exhibited the similar variability with global finger millet germplasm collections. Hence, the variability shown in characterization can be used effectively for finger millet improvement in Sri Lanka.
\end{abstract}

Keywords: Characterization, finger millet, germplasm, morphological traits

\section{INTRODUCTION}

Finger millet, Elusine coracana (L.) Gaertn is a self-pollinated cereal crop belonging to the family Poaceae and subfamily Cloridoideae. It is an allotetraploid with chromosome number of $2 n=4 x=36$ (Khidir and Wet, 1976). Finger millet was native and first domesticated in Ethiopian highland and Western Uganda at least 5,000 years ago and was introduced to India, Sri Lanka and China approximately 3,000 years ago (Upadhyaya et al., 2006). Finger millet is an important subsistence cereal in semi-arid tropics and subtropics which is

\footnotetext{
1 Department of Crop Science, Faculty of Agriculture, University of Peradeniya, Sri Lanka

Ministry of Agriculture, Rajamalwaththa Road, Battaramulla, Sri Lanka

Plant Genetic Resource Center, Department of Agriculture, Gannoruwa, Sri Lanka

4 Institute of International Crop Research Institute for the Semi-Arid Tropics, India

* Corresponding author: ranjalakumarai@gmail.com
} 
cultivated in more than 25 countries in Africa and South Asia. Globally finger millet is cultivated on 5 million hectares of land with a total production of 4.5 million tons of grains (FAO, 2011). It is a popular crop due to high nutritional value which is rich in calcium (1.8$4.8 \mathrm{~g} / \mathrm{kg}$ ), iron (21.7-65.23 mg/kg), zinc (16.5-25 mg/kg) and protein (6-11\%) (Upadhyaya $\mathrm{et}$ al., 2011).

Genebank at the International Crop Research Institute for the Semi-Arid Tropics (ICRISAT) conserves 7,186 germplasm accessions of finger millet originating from 25 countries. To enhance the utilization of finger millet germplasm, a core collection (10\% of entire collection) consisting of 622 germplasm accessions and mini core collection (10\% of core collection or $1 \%$ of entire collection) were developed at ICRISAT, India (Upadhyaya et al., 2006; Upadhyaya et al., 2010).

Phenotypic variations in accessions of finger millet germplasm collections have been reported by several authors. Upadhyaya et al. (2007) evaluated 909 finger millet germplasm accessions originating from Southern and Eastern Africa, and reported that $65.3 \%$ accessions were of green plant type and other accessions were of pigmented type. Other characters such as plant height ranged from 50-180 cm, days to 50\% flowering ranged from 62-96 days, inflorescence length ranged from 30-190 mm and panicle exertion ranged from 0- $215 \mathrm{~mm}$. Bharathi et al. (2013) have evaluated the global finger millet composite of 1,000 accessions.

In Sri Lanka finger millet is the third most important cereal after rice and maize and is cultivated in 6,000 ha with a production and productivity of 6,946 t and $1.2 \mathrm{t} / \mathrm{ha}$ (Agstat, 2014). It is mostly cultivated as a mixed crop with legumes such as mungbean, cowpea and black gram in upland in subsistence farming in dry and intermediate zones of Sri Lanka. Finger millets and other minor millets have been neglected in commercialized agriculture due to its lower productivity. However, demand for finger millet is increasing due to its high nutritional value and medicinal properties.

Plant Genetic Resource Center (PGRC) of Department of Agriculture of Sri Lanka has a collection of 462 germplasm accessions of finger millet (21, 17,3 and 30 accessions obtained from India, Zimbabwe, Nepal and unknown exotic origins, respectively and the remaining 393 have been collected from different districts of all over the country (PGRC, 2016). According to gene bank exploration data, these local germplasm accessions were collected since year 1987 from 18 districts. These germplasm accessions were used for breeding and research activities at the Field Crops Research and Development Institute, Mahailluppallama (FCRDI) during the last 30 years (Anonymous, 2011; Dasanayaka, 2016) morphologically characterized 24 finger millet accessions of PGRC as a pot experiment in green house condition. Although a comprehensive morphological characterization of fairly large number of germplasms of finger millet is fundamental for its breeding programs. However, large number of germplasm were not characterized in open field conditions in uplands of dry zone in past. Therefore, the objective of this study was morphological characterization of local and exotic finger millets accessions collected and conserved at the PGRC, Sri Lanka to facilitate the breeding programme of finger millet.

\section{MATERIAL AND METHODS}

The morphological characterization study included a total of 139 germplasm accessions which were selected from the passport data base of finger millet germplasm at the PGRC, Sri Lanka. Among them 100 accessions were from local collection from 15 districts and 26 accessions were from exotic collection from India, Nepal, Zimbabwe and unknown exotic 
origin, 9 were collected from farmer fields at Mahiyanganaya, and 4 were received from Regional Agriculture Research and Development Center Killinochchiya (Annex 1). The recommended varieties Rawana (exotic accession 10326) and Oshadha (local accession 108) were also included in the assessment as standards.

The evaluation was done in the research fields of FCRDI, Mahailluppallama during the late Maha 2015/16 (Season 1, February 2016 to May 2016) and Maha 2016/17 (Season 2, November 2016 to March 2017) in Randomized Complete Block Design with 2 replicates. The experiment site is located at an altitude of $117 \mathrm{~m}$, longitude of $80^{\circ} 28^{\prime \prime} \mathrm{E}$ and latitude of $80^{\circ} 07^{\prime \prime} \mathrm{N}$. The transplanting was done with 20 days old seedlings. The plot size was $5 \mathrm{~m}$ long and $60 \mathrm{~cm}$ width and the spacing between two plants was $10 \mathrm{~cm}$. The final plant density was 50 plants per row. Basal fertilizer of $65 \mathrm{~kg}$ of urea, $55 \mathrm{~kg}$ of triple super phosphate, 85 $\mathrm{kg}$ of murate of potash and top dressing about $150 \mathrm{~kg}$ of urea per hectare was applied 20 days after transplanting. Chemical control of insect pest and diseases was done to keep the field free of pest and diseases and irrigation was provided whenever needed.

Following IBPGR (1985) as a guide observations were recorded from 5 randomly selected plants from middle of plot for 9 quantitative traits such as plant height $(\mathrm{PH})$, flag leaf blade length (FLL), flag leaf blade width (FLW), peduncle length (PL), panicle exertion (PE), number of finger per panicle (NF), length of longest finger (FL), finger width (FW) and number of productive tillers (NT), days to $50 \%$ flowering (DF) was recorded for plot basis whilst the data such as weight of 20 mature ears $(20 \mathrm{EW})$, threshing ratio (TR; 20 ear grain weight divided by 20 ear weight), grain yield (YLD) and 1,000 grain weight (1,000 GW) were recorded after harvesting.

\section{Data analyses}

The analysis of variance was done for each season and the genotype into season interaction ( $\mathrm{G} \times \mathrm{E}$ ) effect was analyzed by using analysis of variance for two seasons data. The major descriptive statistics were calculated. Correlation coefficient among qualitative characters was estimated by the formulae of Snedecor and Cochran (1980). Principal Component Analysis (PCA) was done using standardize quantitative variables using MINITAB 14 software (MINITAB, 2004). The season 2 data were used for correlation analysis and cluster analysis as the experimental error was lower in season 2 compared to season 1.The scores of first six principle components which accounted for more than $75 \%$ of the total variability were used for the cluster analysis. The similarity matrix was calculated using Euclidean distance and germplasm accessions were grouped using Wards linkage method (Ward, 1963). Dendrogram was obtained from MINITAB 14 software.

\section{RESULTS AND DISCUSSION}

\section{Summary statistics of morphological traits}

The analysis of variance performed for two seasons and result is presented in Table 1 . The characterized accessions were significantly diverse for most of the traits except for finger within season 2 and finger width, number of tillers and flag leaf length in season 1. Analysis of genotype into season interaction effect was significant for days to 50\% flowering, plant height, panicle exertion, weight of 20 mature ears, threshing ratio, grain yield and 1000 grain weight. Hence, other traits which have not shown significant genotype into season interaction 
are highly heritable characters with less or no environment effect. The mean, standard deviation. coefficient of variation, minimum and maximum for 14 quantitative traits for two seasons are given in Table 2.The mean values of traits for two seasons were significantly different for many traits except flag leaf width, finger length and number of fingers per ear. Hence some accession had not shown the similar performance in both seasons. Finger millet is a photo and thermo-sensitive crop, and therefore any fluctuation in day length and daily temperature would have direct effect on the growth and development of vegetative growth of the crop (Senthil et al., 2005).

The highest coefficient of variation was observed in grain yield ( $t / h a)$. Therefore, it provides the opportunity to improve the yield potential by direct selection from the germplasm accessions. Further, panicle exertion, weight of 20 mature ears, number of productive tillers and finger length showed a higher variability (table 2). (Ulaganathan and Nirmala kumara, 2015), reported the highest variability in grain yield per plant, flag leaf blade length and number of productive tillers in 300 finger millet genotypes collected from different geographical regions of India and evaluated in Kharif, 2011 in India.The range for days to $50 \%$ flowering for this study was $47-101$ days. Manyasa, (2013) analyzed the diversity of East African finger millet germplasm and found the days to $50 \%$ flowering 41 to 114 days and finger mini core collection reported the 59-109 days in the same study. It revealed that local finger millet germpalsm showed the almost same variability found tin African and Asian finger millet germplasm. Further grain yield of germplasm accessions ranged from 0.6 to $4.1 \mathrm{t} / \mathrm{ha}$ in pooled data. The similar yield range also recorded East African germplam by Manyasa (2013). However, Bharathi, (2013) reported the $0.02-2.6 \mathrm{t} /$ ha of lower yield in finger millet global composite.

Table 1. Analysis of Variance (ANOVA) of 14 morphological traits for 139 finger millet germplasm accessions during two seasons

\begin{tabular}{|c|c|c|c|c|c|c|c|c|c|}
\hline \multirow{2}{*}{ Trait } & \multirow[b]{2}{*}{ MSS } & \multicolumn{3}{|c|}{ Season 1} & \multicolumn{4}{|c|}{ Season 2} & \multirow[t]{2}{*}{$\begin{array}{c}\mathrm{G} * \mathrm{E} \\
\text { Pro. }\end{array}$} \\
\hline & & EMS & Pro. & CV\% & MSS & EMS & Pro. & $\mathrm{CV} \%$ & \\
\hline DF & 2506 & 2959 & 0.0001 & 6.7 & 141 & 7.27 & 0.0001 & 3.4 & \multirow{2}{*}{$\begin{array}{l}0.0001 \\
0.0001\end{array}$} \\
\hline $\mathrm{PH}$ & 298 & 161 & 0.024 & 17.9 & 131 & 31.19 & 0.0001 & 7.4 & \\
\hline FLL & 3835 & 3375 & 0.769 & 179 & 23.34 & 8.81 & 0.0001 & 4.3 & 0.669 \\
\hline FLW & 60.38 & 10.4 & 0.0001 & 22 & 2.50 & 3.62 & 0.0001 & 7.6 & 0.128 \\
\hline PL & 5896 & 4668 & 0.09 & 36 & 5.71 & 2.80 & 0.0001 & 7.8 & 0.0339 \\
\hline PE & 11.41 & 4.22 & 0.001 & 34 & 10.94 & 4.95 & 0.0001 & 25 & 0.004 \\
\hline FL & 3.72 & 0.59 & 0.0001 & 11 & 5.71 & 0.98 & 0.0001 & 15 & 0.726 \\
\hline FW & 8.73 & 8.5 & 0.451 & 26.1 & 3.26 & 2.73 & 0.149 & 14 & 0.691 \\
\hline NF & 2.35 & 0.85 & 0.0001 & 11 & 3.12 & 0.77 & 0.0001 & 10 & 0.718 \\
\hline NT & 5.31 & 5.27 & 0.49 & 49 & 2.86 & 1.04 & 0.0001 & 28 & 0.124 \\
\hline $20 \mathrm{EW}$ & 1194 & 452 & 0.0001 & 27 & 2076 & 2.42 & 0.0001 & 10 & 0.0001 \\
\hline TR & 0.01 & 0.004 & 0.0001 & 8.6 & 0.01 & 0.00 & 0.0001 & 6.6 & 0.0001 \\
\hline YLD & 1.48 & 0.35 & 0.0001 & 34 & 1.65 & 0.20 & 0.0001 & 23 & 0.0001 \\
\hline $1000 \mathrm{GW}$ & 0.123 & 0.0022 & 0.0001 & 2.2 & 0.11 & 0.01 & 0.0001 & 3.7 & 0.0001 \\
\hline $\begin{array}{l}M S S-M e \\
G^{*} E \text { finge } \\
\text { Note: Plan } \\
(P L), \text { pani } \\
\text { mm }(F W), \\
\text { threshing }\end{array}$ & $\begin{array}{l}\text { m of } S q \\
\text { et geno } \\
\text { ght } \mathrm{cm}\end{array}$ & $\begin{array}{l}\text { re, } M S E \\
\text { es seasor } \\
\text { H), flag } \\
\text { (PE), nı } \\
\text { ductive } \\
\text { rain yiel }\end{array}$ & $\begin{array}{l}\text { an Squar } \\
\text { raction } \\
\text { lade len }\end{array}$ & ror, $C$ & $\begin{array}{l}\text { 7- Coe } \\
\text { flag } l\end{array}$ & ent of $v$ & $\begin{array}{l}\text { tion, Pro. } \\
\text { mm (FLI } \\
\text { est finger }\end{array}$ & robabi & $\begin{array}{l}\text { fF test. } \\
\text { ngth cm } \\
\text { er width }\end{array}$ \\
\hline
\end{tabular}


Table 2. Summary statistics and significance test of means of 14 Qualitative morphological traits derived from 139 Finger millet accessions evaluated in two seasons

\begin{tabular}{|c|c|c|c|c|c|c|c|c|c|c|c|}
\hline \multirow[b]{2}{*}{ Trait } & \multicolumn{5}{|c|}{ late Maha 2016 (Season 1 ) } & \multicolumn{5}{|c|}{ Maha 2016/17 (Season 2) } & \multirow{2}{*}{$\begin{array}{c}\text { T- } \\
\text { test } \\
\text { Prob } \\
\text { abilit } \\
y\end{array}$} \\
\hline & $\underset{\mathbf{n}}{\text { Mea }}$ & SD & CV & Min & $\operatorname{Max}$ & $\underset{\mathbf{n}}{\text { Mea }}$ & SD & $\mathbf{C V}$ & Min & Max & \\
\hline $\mathrm{DF}$ & 81 & 11.1 & 13.8 & 47 & 101 & 78 & 8.39 & 10.7 & 50 & 94 & 0.01 \\
\hline $\mathrm{PH}$ & 70.0 & 9.57 & 13.6 & 37.5 & 93.5 & 75.3 & 8.15 & 10.8 & 52 & 91 & 0.0001 \\
\hline FLL & 30.9 & 4.90 & 15.8 & 18 & 47.5 & 40.4 & 3.44 & 8.51 & 34 & 55 & 0.0001 \\
\hline FLW & 11.0 & 1.60 & 14.6 & 7 & 17.5 & 11.1 & 1.19 & 10.7 & 9 & 16 & 0.667 \\
\hline PL & 17.9 & 2.14 & 11.9 & 8.5 & 24 & 21.5 & 1.75 & 8.14 & 18 & 28 & 0.001 \\
\hline PE & 5.8 & 2.48 & 42.4 & 0 & 11.5 & 8.3 & 2.34 & 28.2 & 4 & 19 & 0.0001 \\
\hline FL & 6.5 & 1.42 & 21.7 & 4 & 15 & 6.4 & 1.68 & 26.0 & 4 & 17 & 0.536 \\
\hline FW & 12.5 & 2.07 & 16.5 & 9 & 28 & 11.6 & 1.30 & 11.1 & 8 & 22 & 0.0001 \\
\hline $\mathrm{NF}$ & 8 & 1.14 & 14.0 & 4.5 & 12 & 8 & 1.25 & 15.2 & 5 & 12 & 0.39 \\
\hline NT & 5 & 1.95 & 42.3 & 2 & 17 & 4 & 1.20 & 33.3 & 1 & 7 & 0.0001 \\
\hline $20 \mathrm{EW}$ & 76 & 24.4 & 32.2 & 18 & 165.5 & 143 & 32.2 & 22.5 & 43.5 & 210 & 0.0001 \\
\hline TR & 0.74 & 0.07 & 9.8 & 0.34 & 0.88 & 0.79 & 0.05 & 6.68 & 0.6 & 0.9 & 0.0001 \\
\hline YLD & 1.73 & 0.86 & 49.9 & 0.14 & 4.05 & 1.94 & 0.72 & 37.3 & 0.3 & 4.61 & 0.028 \\
\hline $1000 \mathrm{GW}$ & 2.08 & 0.25 & 11.9 & 1.46 & 3.04 & 2.31 & 0.24 & 10.4 & 1.7 & 3.09 & 0.0001 \\
\hline
\end{tabular}

Note: Plant height cm (PH), flag leaf blade length $\mathrm{cm}(F L L)$, flag leaf blade width $\mathrm{mm}(\mathrm{FLW})$, peduncle length $\mathrm{cm}$ $(P L)$, panicle exertion $\mathrm{cm}(P E)$, number of finger per panicle $(N F)$, length of longest finger $\mathrm{cm}(F L)$, finger width $\mathrm{mm}(\mathrm{FW})$, number of productive tillers $(N T)$, days to $50 \%$ flowering $(D F)$ weight of 20 mature ears $g(20 \mathrm{EW})$, threshing ratio (TR) and grain yield per ha t/ha (YLD) and 1000 grain weight $g(1000 G W)$

Table 3 showed the most diverse accessions for 14 morphological traits. The shorter plant height $(52-55 \mathrm{~cm})$ and early flowering (50 - 60 days after sowing) were observed in Ac2384 (Jaffna) and TVFM013-1 (Killinochchiya). Further Ac955 (Hambantota) showed the shorter plant height and lower length of longest finger $(4-4.5 \mathrm{~cm})$ too. The Ac2381 (Jaffna) showed the lowest number of fingers (4 fingers) and lower 20 ear weight (45 - $56 \mathrm{~g}$ ). The Acc. 1331 (Ratnepura) showed the shorter plant height and lower length of longest finger $(4-4.5 \mathrm{~cm})$. The lower grain yield (>1.0 t/ha) was recorded in Ac2384 (Jaffna) and TVFM013-1 (Killinochchiya), Ac1815 (Kandy), Ac11350 (Kandy), Ac13361 (Matale) and Ac12629 (Polonnaruwa).

Based on data of two seasons, the Ac8613 (Ratnepura), Ac12038 (Anuradhapura) and Ac10098 (Monaragala) were the late flowering germpalsm (90-94 days to flowering). Among the germplasm studied the Ac7110 (Zimbabwe), Ac12269 (Anuradhapura), Ac7823 (Kandy) and Ac9304 (Exotic) recorded the tallest accessions $(86-90 \mathrm{~cm})$. The longer and wider flag leaf was observed in exotic germplasm. However, wider flag leaf also recorded in few local germpalsm. The length of longest finger $(17 \mathrm{~cm})$ was recorded in exotic finger millet accession Ac7110 origin in Zimbabwe. The higher yield (3 - $4 \mathrm{t} / \mathrm{ha})$ were recorded in germpalsm collected from Mahiyangana (M4 and M9), recommended variety Rawana (Ac10326), two accessions from Kurunegala (Ac12449 and Ac11347), Ac12248 from Kandy and Ac12280 from Anuradhapura. 
Table 3. The most diverse (higher and lower ranks) finger millet germplasm accessions for 13 morphological traits

\begin{tabular}{|c|c|c|}
\hline \multirow[b]{2}{*}{ Trait } & \multicolumn{2}{|c|}{ Germplasm accession number and their origin in abbreviation } \\
\hline & Lower ranks & Higher ranks \\
\hline DF & $\begin{array}{l}\text { EXO-IN_910, JAFF_2384, } \\
\text { JAFF_12968, KILLI_TVFM013-1, } \\
\text { KILLI_TVFM-02 } \\
\text { MON_12927,HAM_955,RAT_1331,KI }\end{array}$ & $\begin{array}{l}\text { EXO_11819,MAT_6586,RAT_8613, } \\
\text { POL_10453,ANU_12038,EXO_1263 } \\
\text { 9,MON_10098 }\end{array}$ \\
\hline $\mathrm{PH}$ & $\begin{array}{l}\text { LLI_TVFM013-1, JAFF_2384, } \\
\text { KILLI_TVFM-04 }\end{array}$ & $\begin{array}{l}\text { EXO-ZIM_7110, } \\
\text { ANU_12269,KAN_7823,EXO_9304 } \\
\text { EXO-ZIM_7110,EXO- }\end{array}$ \\
\hline FLL & $\begin{array}{l}\text { RAT_1329,ANU_12269,EXO_12639,J } \\
\text { AFF_2384,ANU_12225 }\end{array}$ & $\begin{array}{l}\text { NEP_12494,EXO-ZIM_7112,EXO- } \\
\text { ZIM_7107,EXO_9304,EXO- } \\
\text { ZIM_7109 }\end{array}$ \\
\hline FLW & $\begin{array}{l}\text { ANU__12201,JAFF_2384,MAHI_M5,R } \\
\text { AT_1331,MAHI_M8 }\end{array}$ & $\begin{array}{l}\text { EXO_9304,KURU_11352,EXO- } \\
\text { ZIM_7107 }\end{array}$ \\
\hline PL & EXO_9313 & JEP_12494 \\
\hline PE & ANU_5047,RAT_10371 & $\begin{array}{l}\text { EXO-ZIM_7117,MAT_11818,EXO- } \\
\text { NEP_12494 }\end{array}$ \\
\hline FL & $\begin{array}{l}\text { HAM_955,RAT_1331,POL_7769 } \\
\text { JAFF_2384,RAT_1331,ANU_12269,E }\end{array}$ & EXO-ZIM_7110 \\
\hline NF & $\begin{array}{l}\text { XO-IN_910,EXO- } \\
\text { ZIM_7109,ANU_12329 }\end{array}$ & $\begin{array}{l}\text { NELYA_1460,KAN_8660,ANU_77 } \\
70\end{array}$ \\
\hline NT & $\begin{array}{l}\text { KILLI_TVFM-02,EXO- } \\
\text { ZIM_7107,EXO- } \\
\text { ZIM_7112,EXO_9311,EXO- } \\
\text { IN_907,EXO_9304 }\end{array}$ & ANL \\
\hline $\begin{array}{l}20 \mathrm{E} \\
\mathrm{W}\end{array}$ & $\begin{array}{l}\text { JAFF_2384,RAT_1331,KILLI_TVFM } \\
\text { 013-1,KILLI_TVFM-04,MON_12927 }\end{array}$ & $\begin{array}{l}\text { EXO-ZIM_7112,ANU_12276,EXO- } \\
\text { ZIM_7107 }\end{array}$ \\
\hline TR & EXO_9313 & $\begin{array}{l}\text { EXO-IN_10326,KURU_11347 } \\
\text { MAHI_M4,KAN_12248,KURU_113 }\end{array}$ \\
\hline YLD & $\begin{array}{l}\text { KAN_1815,JAFF_2384,KAN_11350, } \\
\text { MAT_12261,KILLI_TVFM013- } \\
\text { 1,POL_12629 }\end{array}$ & $\begin{array}{l}\text { 47,EXO- } \\
\text { IN_10326,KURU_12449,ANU_1228 } \\
\text { 0,MAHI_M9 }\end{array}$ \\
\hline $\begin{array}{l}1000 \\
\text { GW }\end{array}$ & MAHI_M8 & $\begin{array}{l}\text { KURU_11352,EXO- } \\
\text { IN_927,KILLI_TVFM -01,EXO- } \\
\text { IN_10326 }\end{array}$ \\
\hline
\end{tabular}

Note: Plant height cm (PH), flag leaf blade length $\mathrm{cm}(F L L)$, flag leaf blade width $\mathrm{mm}(F L W)$, peduncle length $\mathrm{cm}$ $(P L)$, panicle exertion $\mathrm{cm}(P E)$, number of finger per panicle $(N F)$, length of longest finger $\mathrm{cm}(F L)$, finger width $\mathrm{mm}(F W)$, number of productive tillers $(N T)$, days to $50 \%$ flowering $(D F)$ weight of 20 mature ears $g(20 E W)$, threshing ratio (TR) and grain yield per ha t/ha (YLD) and 1000 grain weight $g(1000 G W)$

\section{Correlation coefficients of morphological traits}

The correlation coefficient among the traits showed consistence in two seasons for many traits. However, there were non consistence correlations between few traits that were observed in two seasons, such as days to $50 \%$ flowering and grain yield. Hence correlation coefficient value of season 2 is presented as season 2 showed lower experimental error 
compared to season 1 (Table 4). Correlation analysis shows the association of the all morphological traits. These associations of traits are very useful in crop improvement through selection. The grain yield is the most prioritized trait in finger millet breeding. Therefore, knowledge on associated traits with grain yield would improve the selection efficiency. The grain yield was significantly positively correlated with $50 \%$ days to flowering, the number of productive tillers, weight of 20 mature ears and threshing ratio. Early characterization studies reported not only above three traits but also many other traits such as plant height and flag leaf length also positive correlated with grain yield (Barathi, 2011). The grain yield was significantly negative correlated with 1000 grain weight and flag leaf width.

Table 4. Pearson's correlation coefficient among the 14 qualitative traits of 139 finger millet accessions at FCRDI, Sri Lanka, 2016/17

\begin{tabular}{|c|c|c|c|c|c|c|c|c|c|c|c|c|c|}
\hline Trait & DF & $\mathrm{PH}$ & FLL & $\begin{array}{l}\text { FL } \\
\mathrm{W}\end{array}$ & PL & PE & FL & FW & $\mathrm{NF}$ & $\mathrm{TC}$ & $\begin{array}{c}20 \\
\mathrm{E} \\
\mathrm{W} \\
\end{array}$ & TR & YLD \\
\hline PH & -0.03 & & & & & & & & & & & & \\
\hline FLL & 0.08 & & $0.59^{*}$ & & & & & & & & & & \\
\hline FLW & $\begin{array}{c}-0.16 \\
-\end{array}$ & $0.45^{*}$ & $*$ & $0.39^{*}$ & & & & & & & & & \\
\hline PL & $\begin{array}{c}0.44^{*} \\
-\end{array}$ & $0.38^{* *}$ & $0.25^{*}$ & & & & & & & & & & \\
\hline $\mathrm{PE}$ & $\begin{array}{c}0.47^{*} \\
-\end{array}$ & $0.36^{* *}$ & $\begin{array}{l}0.25^{*} \\
0.33^{*}\end{array}$ & $\begin{array}{l}0.33^{*} \\
0.35^{*}\end{array}$ & $0.72^{* *}$ & & & & & & & & \\
\hline FL & $\begin{array}{l}0.39^{*} \\
0.186\end{array}$ & $0.45^{* *}$ & & & $0.38^{* *}$ & $0.39^{* *}$ & & & & & & & \\
\hline FW & ${ }^{*}{ }^{*} 5^{*}$ & 0.16 & 0.129 & 0.052 & -0.06 & -0.09 & $\begin{array}{c}-0.04 \\
-\end{array}$ & & & & & & \\
\hline $\mathrm{NF}$ & $0.36^{*}$ & 0.03 & 0.04 & $\begin{array}{c}0.04 \\
-\end{array}$ & $-0.34^{* *}$ & $-0.37^{* *}$ & $\begin{array}{c}0.22^{*} \\
-\end{array}$ & $0.19^{*}$ & & & & & \\
\hline $\begin{array}{l}\text { TC } \\
20 \mathrm{E}\end{array}$ & ${ }^{*}{ }^{*} 8^{*}$ & $-0.27^{* *}$ & -0.14 & $\begin{array}{l}0.28^{*} \\
0.34^{*}\end{array}$ & -0.12 & $-0.18^{*}$ & $0.21^{*}$ & -0.26 & $\begin{array}{c}0.05 \\
0.53^{*}\end{array}$ & & & & \\
\hline W & * & $0.51^{* *}$ & $0.47^{*}$ & & -0.07 & -0.16 & 0.129 & $0.31^{*}$ & & -0.1 & 0.1 & & \\
\hline TR & $\begin{array}{l}0.22^{*} \\
0.40^{*}\end{array}$ & 0.10 & 0.05 & $\begin{array}{c}-0.04 \\
-\end{array}$ & 0.13 & 0.11 & 0.03 & 0.06 & $\begin{array}{c}-0.08 \\
-\end{array}$ & $\begin{array}{c}0.14 \\
0.39^{*}\end{array}$ & $\begin{array}{c}5 \\
0.2\end{array}$ & $0.38^{*}$ & \\
\hline $\begin{array}{l}\text { YLD } \\
1000\end{array}$ & & 0.09 & -0.01 & $0.20^{*}$ & -0.09 & $-0.18^{*}$ & 0.005 & 0.003 & $\begin{array}{c}0.008 \\
-\end{array}$ & * & $\begin{array}{c}7^{*} \\
0.1\end{array}$ & & - \\
\hline GW & -0.13 & $0.23^{*}$ & $0.33^{*}$ & $0.41^{*}$ & $0.23 *$ & $0.27^{*}$ & $0.36^{*}$ & $0.15^{*}$ & $0.02^{*}$ & $0.35^{*}$ & $8^{*}$ & 0.14 & $0.18^{*}$ \\
\hline
\end{tabular}

\section{Principal component analysis (PCA)}

Principal component analysis (PCA) consists of finding a new set of uncorrelated variables (principal components) from original correlated variables. Hence, principal components are the linear combinations of the original variables. PCA showed that first six PCs with eigen value greater than 0.8 have contributed the $78 \%$ of total variability in 139 genotypes for the 14 traits both in seasons (Table 5). The first PCs separated the accessions based on panicle exertion, threshing ratio and grain yield per hectare in season 1. However, season 2 showed similar traits vizplant height, flag leaf length, flag leaf width, peduncle length, panicle exertion and length of longest finger for grouping accessions based on first PC. The flag leaf width and finger length and weight of 20 mature ears and 1000 grain weight negatively 
contributed to PC2 in season 1. But in season 2 showed the days to $50 \%$ flowering, weight of 20 mature ears and number of fingers negatively contributed to PC2.

Therefore, the contribution of traits to different PCs may vary to different seasons or environment. These differences were observed in characterization studies of finger millet global composite collection by Bharathi (2011) in three different locations. The principal component analysis of this study revealed that days to $50 \%$ flowering, plant height, flag leaf length, flag leaf width, finger length, threshing ratio and grain yield per hectare were contributed to first two PCs collectively in 2 seasons. Hence these traits were contributed to the diversity of finger millet genotypes and these traits can be effectively used in breeding programmes to generate the variability. 
Table 5. Principal components coefficients of first six principal components and eigenvalues for 14 traits evaluated in two season and pooled data for 2 seasons

\begin{tabular}{|c|c|c|c|c|c|c|c|c|c|c|c|c|}
\hline \multicolumn{7}{|c|}{ Trait Season-1 (2016) } & \multicolumn{6}{|c|}{ Season-2 (2016/17) } \\
\hline & PC1 & PC2 & PC3 & PC4 & PC5 & PC6 & PC1 & PC2 & PC3 & PC4 & PC5 & PC6 \\
\hline DF & -0.34 & 0.18 & 0.35 & -0.19 & -0.04 & -0.09 & -0.26 & -0.44 & -0.10 & 0.03 & -0.15 & 0.14 \\
\hline $\mathrm{PH}$ & -0.16 & -0.05 & 0.56 & -0.31 & -0.25 & -0.22 & 0.34 & -0.26 & -0.10 & 0.10 & 0.38 & 0.03 \\
\hline FLL & 0.02 & -0.39 & -0.22 & -0.10 & 0.46 & -0.08 & 0.31 & -0.29 & -0.03 & 0.26 & -0.05 & 0.01 \\
\hline FLW & -0.20 & -0.52 & -0.05 & -0.04 & -0.01 & -0.05 & 0.36 & -0.17 & 0.12 & 0.26 & -0.25 & 0.08 \\
\hline PL & 0.28 & 0.03 & -0.09 & -0.60 & -0.28 & 0.03 & 0.37 & 0.14 & -0.24 & 0.02 & 0.02 & 0.43 \\
\hline $\mathrm{PE}$ & 0.45 & -0.03 & -0.03 & -0.33 & -0.10 & -0.03 & 0.37 & 0.18 & -0.20 & -0.01 & -0.05 & 0.39 \\
\hline FL & 0.02 & -0.46 & 0.13 & -0.14 & 0.02 & -0.09 & 0.35 & 0.01 & -0.12 & 0.05 & 0.20 & -0.58 \\
\hline FW & -0.01 & 0.09 & 0.29 & -0.22 & 0.36 & 0.83 & 0.04 & -0.25 & 0.22 & -0.59 & 0.35 & 0.29 \\
\hline NF & -0.34 & -0.20 & 0.14 & 0.07 & 0.03 & 0.07 & -0.15 & -0.38 & 0.27 & 0.17 & -0.17 & 0.16 \\
\hline NT & -0.09 & 0.13 & -0.10 & -0.46 & 0.56 & -0.34 & -0.25 & -0.01 & -0.44 & 0.35 & -0.18 & 0.12 \\
\hline $20 \mathrm{EW}$ & 0.23 & -0.33 & 0.47 & 0.16 & 0.04 & -0.04 & 0.08 & -0.54 & 0.01 & 0.07 & 0.08 & -0.02 \\
\hline $\mathrm{TP}$ & 0.43 & 0.12 & 0.18 & 0.20 & 0.01 & -0.11 & 0.02 & -0.14 & -0.48 & -0.49 & -0.35 & 0.06 \\
\hline Yld & 0.42 & -0.07 & 0.26 & 0.17 & 0.32 & -0.08 & -0.13 & -0.21 & -0.54 & -0.08 & 0.27 & -0.25 \\
\hline $1000 \mathrm{GW}$ & 0.08 & -0.37 & -0.22 & -0.10 & -0.31 & 0.32 & 0.29 & -0.10 & 0.12 & -0.31 & -0.58 & -0.33 \\
\hline Eigenvalue & 3.12 & 2.68 & 1.63 & 1.35 & 1.04 & 0.92 & 3.78 & 2.84 & 1.72 & 1.08 & 0.85 & 0.80 \\
\hline Cumulative & 0.22 & 0.41 & 0.53 & 0.63 & 0.70 & 0.77 & 0.27 & 0.47 & 0.60 & 0.67 & 0.73 & 0.79 \\
\hline
\end{tabular}




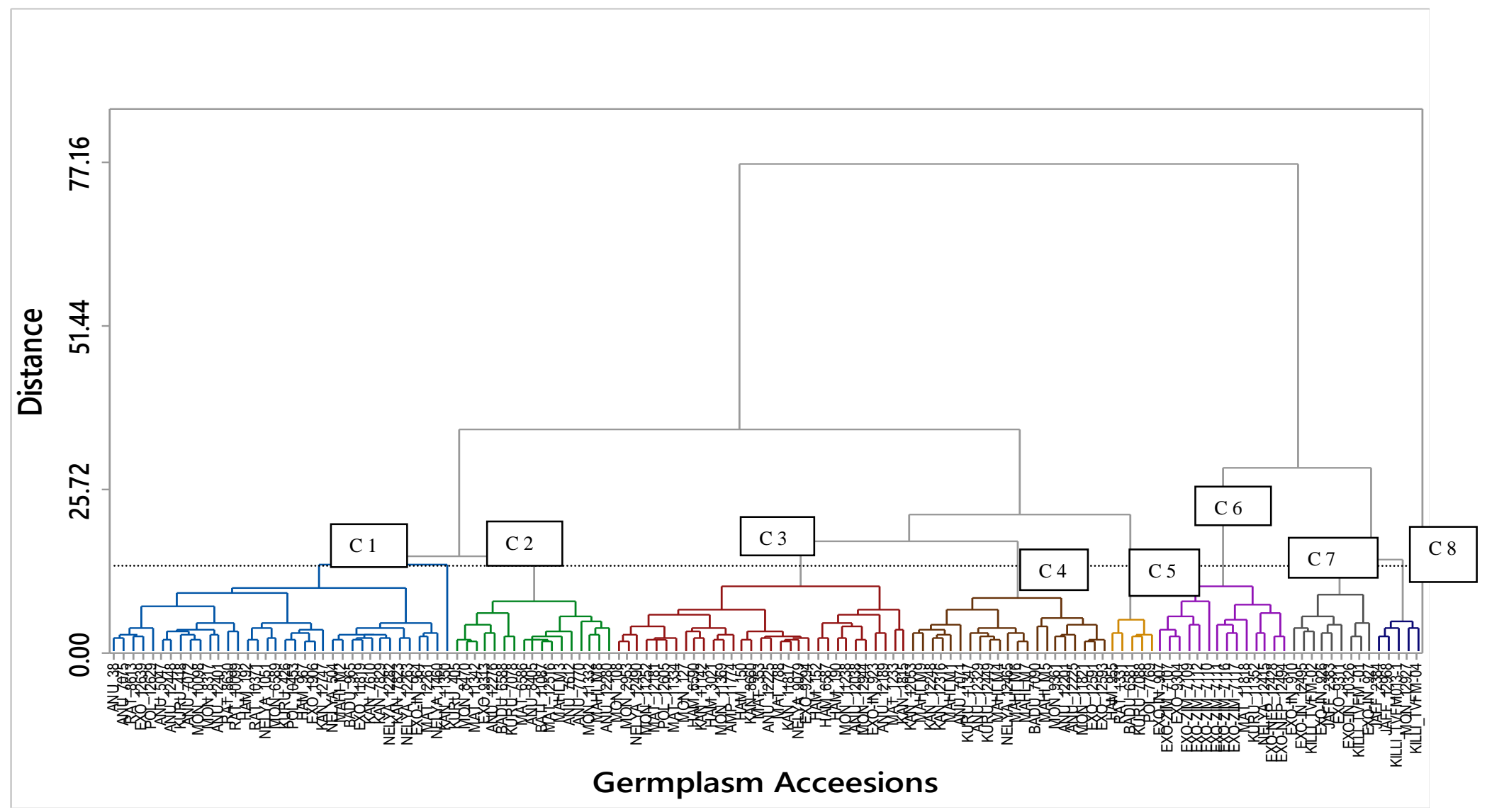

Figure 1. Dendrogram based of six PCs of 14 phenotypic traits of finger millet accessions for pooled data of two seasons using Ward Linkage and Euclidean distance 


\section{Cluster analysis}

The studied finger millet accessions were grouped into two main groups based on days to $50 \%$ flowering at higher level of distance. Then the main groups were divided into sub groups based on flag leaf length, panicle exertion, threshing ratio, weight of 20 mature ears and grain yield. Finally, 8 clusters were identified at lower level of Euclidean distance (Figure 1 and Table 7). The $63 \%$ of total germplasm were grouped into three clusters, $\mathrm{C} 1$ (36 accessions), C3 (31 accessions) and C4 (21 accessions). Cluster C2 with 17 accessions, cluster C6 with 14 accessions and other three clusters (C5, C7 and C8) consisted of less than 10 number of accessions in each. C6, C7 and C8 consisted of shorter and medium days to flowering germplasm and other five clusters were higher days to flowering.

Cluster C8 consisted of early flowering (50-62 days) and lower weight of 20 mature ears (44- $89 \mathrm{~g}$ ) germplasms. Whereas, germplasm in C7, characterizedby early to medium days to flowering (54-75 days) and comparatively higher weight of 20 mature ears (75-161g). The common characters of C6 are early to medium flowering (62-75 days) and longer finger length $(7-17 \mathrm{~cm})$. Cluster C5 included medium days to flower (73-78 days) and shorter finger length $(4-5 \mathrm{~cm})$ genotypes which all were from local collection. The some of the high yielding germplasm (1.98-4.61 t/ha) grouped in C4. Further, C1, C2 and C3 consisted of higher number of fingers per panicle (8-12) compared to other clusters. The traits that contributed to group the germplasm were highly varied from clusters to cluster. The clustering information is very vital for selection for germplam in finger millet breeding for different objectives.

Cluster C6 consisted of all exotic germplasm origin in Zimbabwe and local genotypes such as KURU_11352, MAT_11818 and NELYA_12415.These are Asian finger millet germplasm found in Sri Lanka showed the same performance with African finger millet germplasm introduced from Zimbabwe. Hence, the finger millet germplasm accession collected from different districts and introduced germplasm from different countries were grouped together (Table 7). Ulaganathan and Nirmalakumari, (2015) also observed similar nature in clustering of finger millet genotypes. Therefore, nature of selection forces operating under one eco-geographical region seemed to be similar to other region, as similar traits have been used to breeding and domestication (Salini et al., 2010). 
Table 6. Mean, range and standard deviation (SD) of 14 phenotypic traits of different clusters of finger millet germpalsm accessions for pooled data

\begin{tabular}{|c|c|c|c|c|c|c|c|c|c|}
\hline \multirow{2}{*}{ Trait } & Cluster & C1 & $\mathrm{C} 2$ & $\mathrm{C3}$ & $\mathrm{C4}$ & C5 & C6 & C7 & $\mathrm{C} 8$ \\
\hline & No. acc. & 36 & 17 & 31 & 21 & 5 & 14 & 9 & 5 \\
\hline \multirow{3}{*}{ DF } & Mean & 84 & 82 & 81 & 79 & 75 & 68 & 64 & 55 \\
\hline & Range & $76-91$ & $75-90$ & $75-94$ & $75-85$ & $73-78$ & $62-75$ & $54-75$ & $50-62$ \\
\hline & SD & 3.7 & 4.2 & 3.9 & 2.7 & 2.1 & 4.3 & 7.2 & 4.4 \\
\hline \multirow{3}{*}{ PH } & Mean & 75 & 77 & 76 & 72 & 56 & 86 & 79 & 64 \\
\hline & Range & $61-91$ & $66-90$ & $60-89$ & $59-80$ & $52-60$ & $79-91$ & $70-91$ & $55-73$ \\
\hline & SD & 6.0 & 5.8 & 6.1 & 5.5 & 3.4 & 4.0 & 7.5 & 7.7 \\
\hline \multirow{3}{*}{ FLL } & Mean & 41 & 41 & 41 & 38 & 36 & 46 & 38 & 35 \\
\hline & Range & $35-48$ & $37-43$ & $38-46$ & $34-42$ & $35-38$ & $38-55$ & $35-40$ & $34-38$ \\
\hline & SD & 2.8 & 1.8 & 2.2 & 2.0 & 1.3 & 4.2 & 1.5 & 1.3 \\
\hline \multirow{3}{*}{ FLW } & Mean & 11 & 11 & 11 & 10 & 10 & 13 & 11 & 10 \\
\hline & Range & $9-13$ & $10-12$ & $10-13$ & $9-11$ & $9-11$ & $11-16$ & $9-13$ & $10-11$ \\
\hline & $\mathrm{SD}$ & 0.7 & 0.6 & 0.7 & 0.5 & 0.7 & 1.6 & 1.1 & 0.4 \\
\hline \multirow{3}{*}{ PL } & Mean & 21 & 20 & 22 & 21 & 21 & 24 & 23 & 21 \\
\hline & Range & $18-23$ & $18-21$ & $20-24$ & $18-24$ & $18-22$ & $22-28$ & $21-25$ & $19-24$ \\
\hline & $\mathrm{SD}$ & 1.1 & 1.0 & 1.0 & 1.2 & 1.2 & 1.8 & 1.1 & 1.6 \\
\hline \multirow{3}{*}{ PE } & Mean & 7 & 6 & 9 & 8 & 8 & 13 & 11 & 8 \\
\hline & Range & $5-10$ & $4-8$ & $6-11$ & $6-10$ & $7-9$ & $9-19$ & $9-13$ & $6-11$ \\
\hline & $\mathrm{SD}$ & 1.1 & 0.9 & 1.5 & 1.3 & 0.9 & 2.5 & 1.4 & 1.9 \\
\hline \multirow{3}{*}{ FL } & Mean & 6 & 6 & 6 & 7 & 4 & 9 & 8 & 5 \\
\hline & Range & $5-8$ & $5-8$ & $5-7$ & $5-11$ & $4-6$ & $7-17$ & $7-11$ & $5-7$ \\
\hline & SD & 0.7 & 0.8 & 0.7 & 1.1 & 0.8 & 2.6 & 1.5 & 0.8 \\
\hline \multirow{3}{*}{ FW } & Mean & 12 & 11 & 12 & 11 & 10 & 11 & 11 & 11 \\
\hline & Range & $11-22$ & $11-12$ & $10-14$ & $8-12$ & $10-10$ & $10-14$ & $10-13$ & $10-11$ \\
\hline & SD & 1.8 & 0.6 & 0.8 & 1.0 & 0.1 & 1.0 & 0.8 & 0.7 \\
\hline \multirow{3}{*}{$\mathrm{NF}$} & Mean & 9 & 9 & 8 & 7 & 7 & 7 & 7 & 7 \\
\hline & Range & $8-11$ & $7-12$ & $7-11$ & $6-9$ & $6-8$ & $6-10$ & $6-8$ & $5-8$ \\
\hline & SD & 0.8 & 1.1 & 0.9 & 0.6 & 0.7 & 1.1 & 0.4 & 1.1 \\
\hline \multirow{3}{*}{ NT } & Mean & 3 & 4 & 4 & 4 & 6 & 3 & 2 & 2 \\
\hline & Range & $1-5$ & $3-6$ & $2-6$ & $2-6$ & $6-7$ & $2-4$ & $1-4$ & $1-3$ \\
\hline & SD & 0.8 & 0.8 & 1.0 & 1.0 & 0.4 & 0.6 & 0.7 & 0.8 \\
\hline \multirow{3}{*}{$20 \mathrm{EW}$} & Mean & 167 & 155 & 144 & 132 & 74 & 151 & 110 & 66 \\
\hline & Range & $\begin{array}{l}141- \\
210\end{array}$ & $98-204$ & $\begin{array}{c}121- \\
172\end{array}$ & $\begin{array}{c}105- \\
177\end{array}$ & $50-94$ & $\begin{array}{l}105- \\
200\end{array}$ & $75-161$ & $44-89$ \\
\hline & SD & 16.2 & 25.5 & 13.9 & 18.3 & 18.4 & 26.2 & 31.9 & 17.5 \\
\hline \multirow{4}{*}{ TR } & Mean & 0.79 & 0.73 & 0.80 & 0.83 & 0.79 & 0.81 & 0.75 & 0.69 \\
\hline & Range & $0.72-$ & $0.61-$ & $0.71-$ & $0.74-$ & $0.71-$ & $0.78-$ & $0.67-$ & $0.63-$ \\
\hline & Kange & 0.85 & 0.82 & 0.84 & 0.9 & 0.83 & 0.84 & 0.87 & 0.75 \\
\hline & SD & 0.03 & 0.06 & 0.03 & 0.05 & 0.05 & 0.02 & 0.07 & 0.04 \\
\hline \multirow{4}{*}{ Yld } & Mean & 1.89 & 2.03 & 2.01 & 2.81 & 1.34 & 1.56 & 1.32 & 0.70 \\
\hline & & 0.72 & $1.31-$ & $1.05-$ & $1.98-$ & 0.32 & $0.53-$ & $0.61-$ & $0.32-$ \\
\hline & Rang & 3.38 & 3.52 & 3.24 & 4.61 & 1.91 & 2.69 & 2.31 & 1.26 \\
\hline & SD & 0.6 & 0.5 & 0.5 & 0.6 & 0.6 & 0.5 & 0.5 & 0.4 \\
\hline \multirow{4}{*}{$1000 \mathrm{GW}$} & Mean & 2.41 & 2.07 & 2.25 & 2.26 & 2.09 & 2.49 & 2.64 & 2.13 \\
\hline & Range & $2.17-$ & $1.71-$ & $1.95-$ & $1.98-$ & $1.78-$ & $1.85-$ & 2.24- & $1.81-$ \\
\hline & & 2.74 & 2.22 & 2.58 & 2.62 & 2.38 & 2.89 & 3.09 & 2.31 \\
\hline & SD & 0.1 & 0.1 & 0.2 & 0.2 & 0.3 & 0.3 & 0.3 & 0.2 \\
\hline
\end{tabular}


Table 7. Cluster membership of 139 germplasm accessions characterized in 2016/17 at Mahailluppallama

\begin{tabular}{|c|c|c|}
\hline $\begin{array}{l}\text { Cluste } \\
\text { r No }\end{array}$ & $\begin{array}{l}\text { No of } \\
\text { Genotype } \\
\quad \text { S }\end{array}$ & Germplasm Accessions and their Origin \\
\hline 1 & 36 & $\begin{array}{l}\text { ANU_38, HAM_192, KURU_426, NELYA_504, EXO-IN_964, } \\
\text { BADU_965, HAM_967, NELYA_1051, NELYA_1460, } \\
\text { EXO_1906, ANU_5047, KURU_418, MON_6589, KAN_7610, } \\
\text { ANU_7072, ANU_7075, KAN_7823, KAN_7829, MON_8317, } \\
\text { RAT_8613, RAT_8630, MON_10098, RAT_10099, AT_10371, } \\
\text { POL_10453, KAN_11350, EXO_11819, MAT_12261, } \\
\text { ELYA_12263, NELYA_12282, ANU_12401, ANU_12448, } \\
\text { POL_12629, EXO_12639, KAN_12747, MAHI_M2 }\end{array}$ \\
\hline 2 & 17 & $\begin{array}{l}\text { KURU_405, MAT_6586, BADU_6588, KURU_7078, ANU_7612, } \\
\text { ANU_7770, ANU_8405, MON_8470, EXO_9313, BATI_11087, } \\
\text { MON_11332, MAT_11342, ANU_12276, ANU_12280, } \\
\text { MAT_12516, MAHI_M3, MAHI_M8 }\end{array}$ \\
\hline 3 & 31 & $\begin{array}{l}\text { MON_108, MON_127, HAM_150, HAM_152, HAM_190, } \\
\text { MAT_353, MAT_788, EXO-IN_923, MAT_1233, KAN_1815, } \\
\text { MON_2953, HAM_3021, HAM_6587, HAM_6590,KAN_8660, } \\
\text { NELYA_9079, EXO_9294, MON_11369, KAN_11142, } \\
\text { MON_11238, MON_11252, MAT_11334, AMP_11774, } \\
\text { KAN_11817, ANU_12038, MAT_12181, ANU_12189, } \\
\text { ANU_12225, NELYA_12490, POL_12605, MON_12944 }\end{array}$ \\
\hline 4 & 21 & $\begin{array}{l}\text { KAN_12053, ANU_7071, BADU_7090, MON_9361, } \\
\text { KURU_11347, MON_11821, ANU_12201, ANU_12225, } \\
\text { KAN_12248, KAN_12316, ANU_12329, KURU_12449, } \\
\text { NELYA_12465, EXO_12591, EXO_12593,MAHI_M1, } \\
\text { MAHI_M4, MAHI_M5, MAHI_M6, MAHI_M7, MAHI_M9 }\end{array}$ \\
\hline 5 & 5 & HAM_955, RAT_1331, BADU_6581, KURU_7088, POL_7769 \\
\hline 6 & 14 & $\begin{array}{l}\text { EXO-IN_907, EXO-ZIM_7107, EXO-ZIM_7109, EXO-ZIM_7110, } \\
\text { EXO-ZIM_7111, EXO-ZIM_7112, EXO-ZIM_7116, EXO- } \\
\text { ZIM_7117, EXO_9304, KURU_11352, MAT_11818, } \\
\text { NELYA_12415, EXO-NEP_12428, EXO-NEP_12494 }\end{array}$ \\
\hline 7 & 9 & $\begin{array}{l}\text { EXO-IN_910, EXO-IN_926, JAFF_2383, EXO_9311, EXO- } \\
\text { IN_10326, EXO-IN_927, EXO-IN_12495, KILLI_TVFM -01, } \\
\text { KILLI_TVFM-02 }\end{array}$ \\
\hline 8 & 5 & $\begin{array}{l}\text { JAFF_2384, JAFF_12968, MON_12927, KILLI_TVFM013-1, } \\
\text { KILLI_TVFM-04 }\end{array}$ \\
\hline
\end{tabular}

\section{CONCLUSIONS}

The characterization of finger millet germplasm accessions provides information of variability of germplasm exists in the country. This study revealed that Sri Lankan finger millet germplasm collection showed the similar variability for evaluated qualitative 
morphological characters such as days to flowering, grain yield, length of the longest finger with finger millet global composite as well as finger millet mini core collection at ICRISAT, India. The traits with higher variability such as grain yield, panicle exertion, weight of 20 mature ears, number of productive tillers and length of the longest finger and traits with significant positive correlation with grain yield can be used to select germplasm accessions for direct introduction to farmers through adaptive research. Moreover, finger millet improvement through hybridization and selection can be done tedious manual crossing by selecting parents from different clusters for different breeding objectives.

\section{ACKNOWLEDGEMENTS}

Asia Pacific Association of Agriculture Research Institutes (APAARI) is greatly acknowledged for the financial support given for the research activities.

\section{REFERENCES}

Agstat (2014). Pocket book of Agriculture Statistics. Vol XI, Socio Economics and Planning Center, Department of Agriculture, Sri Lanka.

Anonymous (2011). Annual Research Report, Field Crops Research and Development Institute, Mahailluppallama.

Bharathi, A., Veerabadhira, P., Gowda, C.L.L., Upadhyaya, H.D. (2013). Genetic Variability and Correlation Analysis in Global Composite Collection of Finger Millet (Eleusine coracana (L.) Gaertn). Madras J. Agriculture. p. 100.

Bharathi, A. (2011). Phenotypic and genotypic diversity of global finger millet (Eleusine coracana (L.) Gaertn.) composite collection. PhD thesis, Tamil Nadu Agricultural University, Coimbatore.

Dasanayaka, P.N. (2016). Characterization of some ex situ conserved finger Millet (Eleusine coracana (L.)) Germplasm Accessions in Sri Lanka. International Journal of Multidisciplinary Studies (IJMS), 3(2). 141-150.

Khidir, W.H. and De Wet, J. M. J. (1976). Domestication of Eleusine coracan. Econ. Bot . 30, 199-208.

FAO (2011). FAOSTAT database[on line].[Accessed on 14.04.2018]. Available at http://www/fao.org.

IBPGR, (1985). Descriptors for finger millet (Eleusine coracana (L.) Gaertn). Rome, Italy: International Board for Plant Genetic Resources.

Manyasa, E.O. (2013). A study of the diversity, adaptation and genetic effects for blast resistance and yield traits in East African finger millet (Eleusine coracana (L.) Gaertn) landraces. PhD thesis, Plant Breeding School of Agricultural, Earth and Environmental Sciences, College of Agriculture, Engineering and Science University of KwaZulu-Natal Pietermaritzburg Republic of South Africa. 
MINITAB (2004) Minitab users guide, Release 14.3 Minitab Inc. United Kingdom.

PGRC (2016). Finger millet germplasm data base. Plant genetic resource Center, Department of Agriculture, Gannoruwa, Peradenya.

Senthil, N.A., NirmalaKumari, A., John Joel, B., Selvi, T.S., Raveendran, K., Ramamoorthy and Ramanathan, A. (2005). Small Millets for Nutritional Security, Kalaiselvam, Pathipagam, Coimbatore.

Snedecor, G.W. and Cochran,W.G. (1980). Statistical Methods. $7^{\text {th }}$ Ed. Iowa State University Press, USA.

Salini, K.A., Nirmalakumari, A., Muthiah, R., Senthil, N.A. (2010). Evaluation of proso millet (Panicum miliaceum L.) germplasm collections. Elect. J. Plant Breed. 1(4), 489-499.

Ulaganathan, V. and Nirmalakumari, A. (2015). Finger millet germplasm characterization and evaluation using principal component analysis. SABRAO J. Breed. Genet. 47(2), 79-88.

Upadhyaya, H.D., Gowda, C.L.L., Pundir, R.P.S., Reddy, V.G. and Singh, S. (2006). Development of core subset of finger millet germplasm using geographical origin and data on 14 morpho-agronomic traits. Genetic Resources and Crop Evolution, 53, 679-685.

Upadhyaya, H.D., Gowda, C.L.L. and Reddy, V.G. (2007). Morphological diversity in finger millet germplasm introduced from Southern and Eastern African. SAT eJournal. 3(1), $1-3$.

Upadhyaya, H.D., Sarma, N.D.R.K., Ravishankar, C.R., Albrecht, T., Narasimhudu, Y. Singh, S.K., Varshney, S.K., Reddy, V.G., Dwivedi, S.L., Wanyera, N., Oduori, C.O.A., Mgonja, M.A., Kisandu, D.B., Parzies, H.K. and Gowda, C.L.L. (2010). Developing a minicore collection in finger millet using multi-location data. Crop Science, 50, 1924-1931.

Upadhyaya, H.D., Ramesh, S., Sharma S., Singh, S.K., Varshney, R.K., Sarma, N.D.R.K., Ravishankar. C.R., Narasimhudu, Y., Reddy, V.G., Sahrawat, K.L., Dhanalakshmi, T.N., Mgonja, M.A., Parzies, H.K., Gowda, C.L.L. and Singh Sube. (2011). Genetic diversity for grain nutrients contents in a core collection of finger millet (Eleusine coracana (L.) Gaertn.) germplasm. Field Crops Research, 121, 42-52.

Ward, J. (1963). Hierarchical grouping to optimize an objective function. J. Am. Stat Assoc. 38, L236-244. 
Annex 1:Characterized Finger millet germplasm accession number and their place of collection.

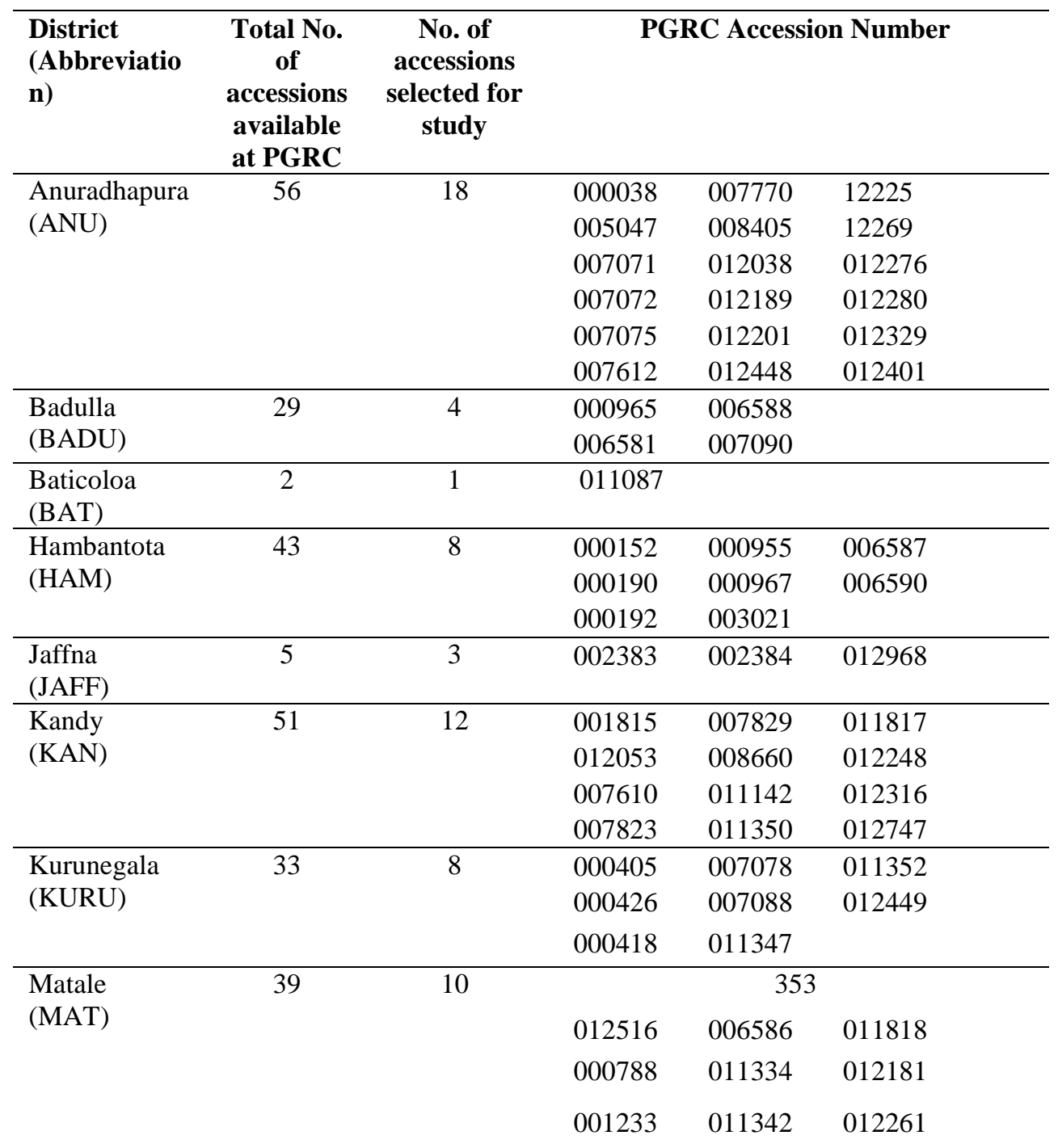

\begin{tabular}{llllll}
\hline Monaragala & 53 & 16 & 108 & 008443 & 011238 \\
(MON) & & 000127 & 008470 & 011252 \\
& & 002953 & 009361 & 011332 \\
& & 006589 & 010098 & 011821 \\
& & 008317 & 011369 & 012927 \\
& & 012944 & & \\
\hline $\begin{array}{l}\text { NuwaraEliya } \\
\text { (NELYA) }\end{array}$ & 33 & 9 & 000504 & 009079 & 012415 \\
& & 001051 & 012263 & 012465
\end{tabular}




\begin{tabular}{|c|c|c|c|c|c|}
\hline & & & 001460 & 012282 & 012490 \\
\hline $\begin{array}{l}\text { Polonnaruwa } \\
\text { (POL) }\end{array}$ & 15 & 4 & $\begin{array}{l}007769 \\
010453\end{array}$ & 012605 & 012629 \\
\hline Putlum & 4 & 0 & & & \\
\hline $\begin{array}{l}\text { Ratnepura } \\
\text { (RAT) }\end{array}$ & 23 & 6 & $\begin{array}{l}001329 \\
001331\end{array}$ & $\begin{array}{l}008613 \\
008630\end{array}$ & $\begin{array}{l}010099 \\
010371\end{array}$ \\
\hline $\begin{array}{l}\text { India } \\
\text { (Exo_IN) }\end{array}$ & 21 & 7 & $\begin{array}{l}000907 \\
000910 \\
000923\end{array}$ & $\begin{array}{l}000926 \\
000964\end{array}$ & $\begin{array}{l}000927 \\
012495\end{array}$ \\
\hline $\begin{array}{l}\text { Nepal } \\
\text { (EXO_NEP) }\end{array}$ & 3 & 2 & 012428 & 012494 & \\
\hline $\begin{array}{l}\text { Zimbabwe } \\
(\text { EXO_ZIM) }\end{array}$ & 17 & 7 & $\begin{array}{l}007107 \\
007109 \\
007110\end{array}$ & $\begin{array}{l}007111 \\
007112\end{array}$ & $\begin{array}{l}007116 \\
007117\end{array}$ \\
\hline $\begin{array}{l}\text { Exotic } \\
\text { "Unknown' } \\
(\mathrm{EXO})\end{array}$ & 30 & 10 & $\begin{array}{l}001906 \\
009294 \\
009304 \\
012639\end{array}$ & $\begin{array}{l}009311 \\
009313 \\
010326\end{array}$ & $\begin{array}{l}011819 \\
012591 \\
012593\end{array}$ \\
\hline $\begin{array}{l}\text { Killinochchi } \\
\text { (KILLI) }\end{array}$ & & 4 & $\begin{array}{l}\text { TVTM013- } \\
\text { TVFM-02 }\end{array}$ & ${ }^{1}$ & $\begin{array}{l}M-01 \\
M-04\end{array}$ \\
\hline $\begin{array}{l}\text { Mahiyangana } \\
\text { ya } \\
(\mathrm{MAHI})\end{array}$ & $\begin{array}{l}\text { Collection } \\
\text { from } \\
\text { farmer } \\
\text { field }\end{array}$ & 9 & $\begin{array}{l}\text { M1 } \\
\text { M2 } \\
\text { M3 }\end{array}$ & $\begin{array}{l}\text { M4 } \\
\text { M5 } \\
\text { M6 }\end{array}$ & $\begin{array}{l}\text { M7 } \\
\text { M8 } \\
\text { M9 }\end{array}$ \\
\hline
\end{tabular}

Total No.

Acc. 462

139

Source: PGRC, Sri Lanka. 